\title{
A reproducible differential blood cell count without a cytometer or specific markers
}

\author{
TOZETTI, P. B. ${ }^{1}$, PINTO, F. E. ${ }^{1}$, PEREIRA NETO, E. ${ }^{2}$, \\ ANDRADE T. U. ${ }^{1}$, ENDRINGER, D. C. ${ }^{1}$ and LENZ, D. ${ }^{1}$ *
}

\author{
${ }^{1}$ Masters Program in Pharmaceutical Sciences, Universidade de Vila Velha - UVV, \\ Rua Comissário José Dantas de Melo, 21, Boa Vista, CEP 29102-770, Vila Velha, ES, Brazil \\ ${ }^{2}$ Masters Program in Animal Sciences, Universidade Vila Velha - UVV, \\ Rua Comissário José Dantas de Melo, 21, Boa Vista, CEP 29102-770, Vila Velha, ES, Brazil \\ *E-mail: dominik.lenz@gmail.com
}

\begin{abstract}
Introduction: A differential blood cell count represents a substantial component of the daily clinical routine. The aim of this study was to conduct automated high-throughput analyses of light microscopy images of leukocytes with unspecific staining (hematoxylin-eosin, HE) and to classify the resulting subgroups (lymphocytes, monocytes and neutrophils). Materials and Method: The software package CellProfiler was used for the image analysis and cell classification. The results were compared to those from hematological laboratories that analyzed the same samples. Results: There was a high similarity between the results obtained by image analysis and those from the hematological laboratories, with an $r^{2}=0.95$ for the differential count and an $r^{2}=0.89$ for the total count. Conclusion: Differential blood cell count using light microscopy, nonspecific dyes and advanced image analysis is accurate, reproducible, and less expensive compared to other techniques. The results also showed a strong correlation when compared to traditional methods.
\end{abstract}

Keywords: cytometry, blood cell count, high-throughput analyses, image analyses, machine learning.

\section{Introduction}

A differential blood cell count (DBCC) represents a substantial component of the daily clinical routine (MITTAG and TARNOK, 2011). The DBCC reports the cell count per volume and the percentages of leukocyte subgroups. Although the parameters quantified in a DBCC do not deliver information to produce a specific diagnosis, the DBCC provides important data about the current state of a patient with a known diagnosis (MITTAG and TARNOK, 2011).

A DBCC is usually conducted either manually or using cytometric techniques with specific fluorescent markers (MITTAG, LENZ, SMITH et al., 2005). Cytometry is an expensive procedure (LENZ, LENK, MITTAG et al., 2005). Using morphological characteristics to manually count each individual cell is tedious, time consuming and not reproducible (MITTAG et al., 2005). In addition, during the manual cell count, fewer cells are counted compared to other methods. A manual count is more commonly conducted in developing countries, such as Brazil and South Africa (SHAPIRO and PERLMUTTER, 2005)

We hypothesized that the lack of reproducibility substantially impairs the diagnostic quality of a manual cell count. Therefore, in this study, a manual cell count (using light microscopy and hematoxylin eosin) was combined with a high-throughput image analysis and a subsequent classification process to identify and calculate the percentages of leukocyte subgroups (lymphocytes, monocytes and neutrophils).The software for both image analysis (CellProfiler) ( KAMENTSKY, JONES, FRASER et al., 2011) and the subsequent statistical processing (Tanagra) (RAKATOMALALA, 2005) are freely available.
The advantages of a reproducible cell count based on high-throughput image analysis are obvious: images of each sample are saved on a hard drive and the results can be verified anytime. Because of the free nature of the software used for the present study, there is no financial burden, other than a computer and a digital camera. Finally, images saved on a hard disk can be used for forensic purposes.

\section{Materials and Methods}

\subsection{Samples}

Peripheral blood samples from 15 volunteers were collected. One aliquot of each sample was sent to a traditional hematology laboratory to carry out a DBCC for a subsequent comparison with the results of the present study. The traditional DBCC count is done manually. Another aliquot was used to be stained with hematoxylin and eosin (HE) and subsequent image analyses. A third aliquot was used for determining the leukocyte counts per $\mathrm{mL}$ in a Neubauer chamber.

All the volunteers who donated samples for this study provided their consent. The present study was also approved by the Ethical Committee on Research involving Human Subjects at the University of Vila Velha, registration $N^{\circ} 184 / 09$, and have therefore been performed in accordance with the ethical standards.

\subsection{Differential leukocyte count}

Blades with an aliquot of each sample were prepared with HE staining as previously described in Saltini, Hance, Ferrans et al. (1984). An average of 300 images were collected 
using a light microscope (Eikonal Brazil, LGD3) equipped with a digital camera (EUROKAM 3.0). The images of each sample were saved in $\mathrm{HD}$.

\subsection{Leukocyte count per $m L$}

The samples were prepared according to the instructions of Fischbach and Dunning (2009). Images of the samples were obtained using the equipment cited above (differential leukocyte count). Images of four fields of the Neubauer chamber were taken as described by Mittag, Lenz, Smith et al. (2005).

\subsection{Image analysis}

The free software CellProfiler 2.0 was used for the image analysis. Initial image analysis was performed for the differential counting of leukocytes. The main window of CellProfiler allows the user to program the pipelines (modules) that will be of interest to the search. Each pipeline performs a specific task in the image. The data file generated during the analysis provides morphological and intensity data for each object identified.

Image analysis for the total leukocyte count used identical methods as described above with only the amount of identified cells quantified. The count was performed as described by Fischbach and Dunning (2009).

\subsection{Classifying leukocyte subtypes}

Subsequently, the samples were evaluated statistically. Within the Excel file provided by CellProfiler, each row represented an identified object and each column represented a quantified parameter. A new column was added in which an experienced cell biologist identified and labeled each type of cell (monocytes, lymphocytes, and neutrophils) based on the images of the identified objects and the original image. At this point, non-cellular artifacts were excluded.

After each type of cell was identified, the Tanagra software was used to find the parameters that effectively and accurately predicted the origins of the cells (Fisher filtering and data mining respectively). Using the parameters found during data mining, graphics were drawn. In these graphics, the position of each subpopulation was located and the values for the subsequent filtering and prediction were defined. An average and range of values for the best parameters were obtained for the three cell types. A filter was created using this average; this filter was implemented using the Java SE platform (Sun Microsystems, Inc.) and was used to predict the origin of the cells automatically.

\subsection{Regression}

Finally, the results were compared to those obtained from a traditional laboratory hematology analysis. For comparing the results, a linear regression was performed for the count of the subpopulations and for the leukocyte count per mL.

\section{Results}

During the image analysis objects of interest (i.e., leukocytes) were automatically identified by the CellProfiler software. The morphological and intensity parameters were quantified for each identified object. An image with numerical data on the identified objects was saved on a hard disk for subsequent identification of the types of cells.

After finding the parameters best capable of predicting the cell's origin, values were calculated for a subsequent automated prediction using the programmed filter as described above.

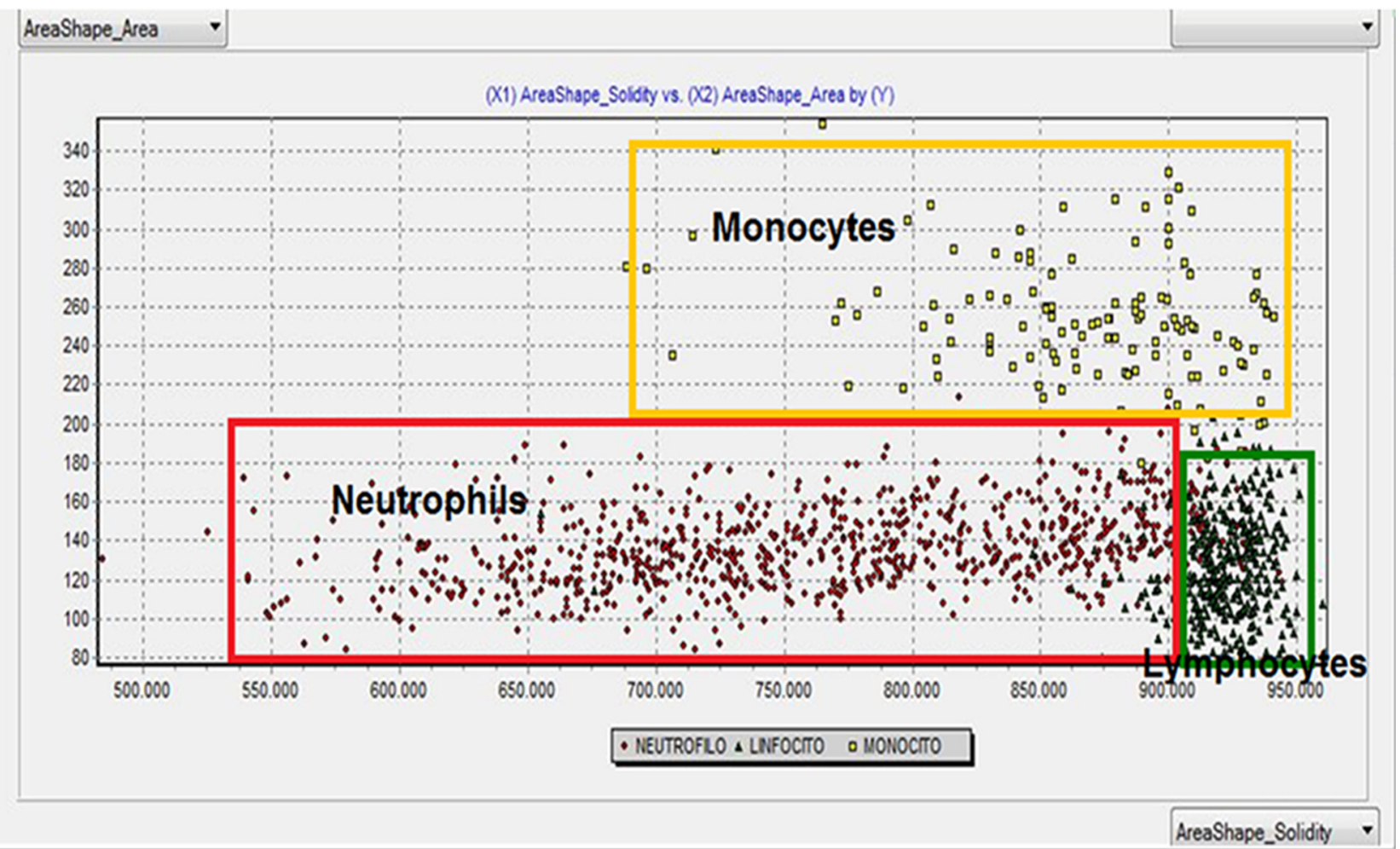

Figure 1. Depiction of separating the three subpopulations (monocytes, lymphocytes and neutrophils) using the parameters detected by feature selection of the software Tanagra. Round objects depict neutrophils, triangles depict monocytes, and square objects depict monocytes. 
Figure 1 shows the separation of the subpopulations using the selected parameters.

After filtering, the results obtained from CellProfiler were compared to the results obtained from the laboratory. The linear regression of CellProfiler's results displayed a strong correlation to the count differential $\left(r^{2}=0.95\right)$ and global count $\left(r^{2}=0.89\right)$.

\section{Discussion}

Many of the studies mentioned above used expensive specific markers, whereas the present study identified and characterized cells using parameters of the nuclei rmorphology of the cells, employing only nonspecific markers (HE). Misselwitz, Strittmatter, Periaswamy et al. (2010) and Selinummi, Ruusuvuori, Podolsky et al. (2009) demonstrated the possibility of identifying and characterizing cells by employing morphometry. With the development of this method, cytometry is able to qualitatively and quantitatively analyze leukocyte subtypes (MISSELWITZ, STRITTMATTER, PERIASWAMY et al., 2010; CARPENTER, 2009). This study contributes to the evolution of this technology.

The advantages of using image analysis with nonspecific markers are obvious: hematologic knowledge of the smallest animals can be generated, which has not previously been possible because too much sample volume is required (ALLENDER and FRY, 2008; KANIA, 2008). Additionally, hematological knowledge can be generated for many species that lack specific antibodies (KANIA, 2008).

Decreasing the cost of cellular diagnostics is of great importance and has been the subject of many studies. Treatments for viruses such as HIV require a periodic differential blood count. Since the appearance of HIV, an extensive effort has pushed to reduce the cost of cellular diagnostics, particularly in countries such as South Africa (SHAPIRO and PERLMUTTER, 2005). The methodology described in this study used equipment and markers found in most research laboratories: HE to stain the cells, a desktop computer, a digital camera, and a light microscope. The software for both the image analysis and statistical processing are free.

The method described in this study is more reliable than a manual cell count because the analyses can be repeated and its results can be verified morphologically. Furthermore, considerably more cells were counted in this study than during a manual cell count $(1,500$ cells on average). The manual cell count is time consuming, tedious, and not reproducible (MITTAG, LENZ, SMITH et al., 2005). However, DBCC remains manually performed in most countries (ALI, MOIZ and OMER, 2010).

The software was programmed to recognize leukocytes but can also be programmed to recognize any object. The utility of this design includes the capability to recognize various characteristics of the cells (i.e., blasts, atypical lymphocytes, and immature granulocytes), which certain devices do not detect (BACALL, 2009). The software would also be able to identify diseases such as acute leukemia, which displays pathognomonic changes in morphology of the cells (CRAIG and FOON, 2008).

The proposed method allows the results to be reproduced at any time, which is not possible when labs still use a manual count due to the need for analyzing another sample or different fields counted on the same slide, thereby generating differences in the results. With images properly stored on a hard drive, the analysis can be repeated for verification purposes.

A comparison of the results of hematological laboratory and the Cellprofiler delivers a linear regression of $r^{2}=0.95$ for differential count, and $\mathrm{r}^{2}=0.89$ for total count. Demonstrating a strong correlation between the proposed method and the usual methods, suggest that this method may be effective in quantifying leukocytes.

Eosinophils and basophils were excluded from the classification because not enough cells were detected to train the computer with their morphology and subsequently classify more cells of the same type. However, this subject is certainly interesting and should be further investigated.

The use of an autofocussing camera is highly recommended because texture features can be quantified. Using texture features, many additional parameters could be quantified, potentially increasing the accuracy of the results.

\section{Conclusion}

We concluded that the cell count method developed in this study using light microscopy, advanced image analysis, and nonspecific dye is accurate, reproducible and less tedious compared to manually counting cells. This method can replace manual counts in thousands of existing laboratories because it employs equipment present in these laboratories.

\section{Acknowledgements:}

The grant of FAPES for Pablo Tozetti is greatly acknowledged.

\section{Conflict of interest}

None of the authors of this paper has a financial or personal relationship with other people or organizations that could inappropriately influence or bias the content of the paper.

\section{References}

ALI, AF., MOIZ, B. and OMER, S. Is manual reticulocyte count a reliable option for under resourced countries? The Journal of the Pakistan Medical Association, 2010, vol. 60, n. 11, p. 892-896. PMid:21375188.

ALLENDER, MC. and FRY, MM. Amphibian hematology. The Veterinary Clinics of North America: Exotic Animal Practice, 2008, vol. 11, n. 3, p. 463-480. http://dx.doi.org/10.1016/j. cvex.2008.03.006. PMid:18675729.

BACALL, NS. Analisador automático hematológico e a importância de validar novos equipamentos em laboratórios clínicos. Revista Brasileira de Hematologia e Hemoterapia, 2009, vol. 31, n. 4, p. 218-220. http:// dx.doi.org/10.1590/S1516-84842009000400006.

CARPENTER, AE. Extracting rich information from images. Methods in Molecular Biology, 2009, vol. 486, p. 193-211. http://dx.doi. org/10.1007/978-1-60327-545-3_14. PMid:19347625.

CRAIG, FE. and FOON, KA. Flow cytometric immunophenotyping for hematologic neoplasms. Blood, 2008, vol. 111, n. 8, p. 3941-3967. http://dx.doi.org/10.1182/blood-2007-11-120535. PMid:18198345.

FISCHBACH, FT. and DUNNING, MB. A manual of laboratory and diagnostic tests. Philadelphia: Lippincott Williams \& Wilkins, 2009.

KAMENTSKY, L., JONES, TR., FRASER, A., BRAY, MA., LOGAN, DJ., MADDEN, KL., LJOSA, V., RUEDEN, C., ELICEIRI, KW. and CARPENTER, AE. Improved structure, function and compatibility for CellProfiler: modular high-throughput image analysis software. 
Bioinformatics, 2011, vol. 27, n. 8, p. 1179-1180. http://dx.doi. org/10.1093/bioinformatics/btr095. PMid:21349861.

KANIA, SA. Flow cytometry applications for exotic animals. The Veterinary Clinics of North America: Exotic Animal Practice, 2008, vol. 11, n. 3, p. 583-595. http://dx.doi.org/10.1016/j.cvex.2008.03.002. PMid:18675736.

LENZ, D., LENK, K., MITTAG, A., ADAMS, V., KRÄNKEL, N., BOLDT, A., GERSTNER, AO., RAIDA, M., WEISS, T., HAMBRECHT, R. and TARNOK, A. Detection and quantification of endothelial progenitor cells by flow and laser scanning cytometry. Journal of Biological Regulators and Homeostatic Agents, 2005, vol. 19, n. 3-4, p. 180-187. PMid:16602635.

MISSELWITZ, B., STRITTMATTER, G., PERIASWAMY, B., SCHUMBERGER, MC., ROUT, S., HORVATH, P., KOZAK, K. and HARDT, WD. Enhanced CellClassifier: a multi-class classification tool for microscopy images. BMC Bioinformatics, 2010, vol. 11, n. 1, p. 30 . http://dx.doi.org/10.1186/1471-2105-11-30. PMid:20074370.

MITTAG, A. and TARNOK, A. Recent advances in cytometry applications: preclinical, clinical, and cell biology. Methods in Cell Biology, 2011, vol. 103, p. 1-20. http://dx.doi.org/10.1016/B9780-12-385493-3.00001-2. PMid:21722797.

MITTAG, A., LENZ, D., SMITH, P., PACH, S. and TARNOK, A. Small and cheap: accurate differential blood count with minimal sample volume by Laser Scanning Cytometry (LSC). In Proceedings of the SPIE 5692, Advanced Biomedical and Clinical Diagnostic Systems III, 2005. USA: SPIE, 2005. p. 79.

RAKATOMALALA, R. TANAGRA: un logiciel gratuit pour l'enseignement et la recherché. In Proceedings of the 5th Journées d'Extraction et Gestion des Connaissances, 2005. Lyon: TANAGRA, 2005. vol. 2, p. 697-702.

SALTINI, C., HANCE, AJ., FERRANS, VJ., BASSET, F., BITTERMAN, $\mathrm{PB}$. and CRYSTAL, RG. Accurate quantification of cells recovered by bronchoalveolar lavage. The American Review of Respiratory Disease, 1984, vol. 130, n. 4, p. 650-658. PMid:6385789.

SELINUMMI, J., RUUSUVUORI, P., PODOLSKY, I., OZINSKY, A., GOLD, E., YLIHARJA, O., ADEREM, A. and SHMULEVICH, I. Bright field microscopy as an alternative to whole cell fluorescence in automated analysis of macrophage images. PLoS One, 2009, vol. 4, n. 10, p. e7497. http://dx.doi.org/10.1371/journal.pone.0007497. PMid:19847301.

SHAPIRO, HM. and PERLMUTTER, NG. Personal cytometers: slow flow or no flow? Cytometry Part A, 2005, vol. 69, n. 7, p. 620-630.

Received August 25, 2014

Accepted October 7, 2015 